\title{
Review of methods and approaches of abandoned lands identification
}

\author{
$E$ Barbotkina ${ }^{1}$, Ie Dunaieva ${ }^{1, *}, V$ Popovych $^{1}$, and $V$ Pashtetsky $^{1}$ \\ ${ }^{1}$ Research Institute of Agriculture of Crimea, 150 Kievskaya str., Simferopol, Crimea, 295453, Russia
}

\begin{abstract}
The paper describes the causes of abandonment of agricultural land in various regions of the world, as well as in Russia and the Republic of Crimea, and explores the existing methods and approaches for identifying such lands using data from remote sensing of the Earth. To identify abandoned lands in Crimea, the MODIS time series analysis method of remote sensing data was used together with ground data on the location of arable land using Vega-Science service. The territory of Krasnogvardeisky and Belogorsky municipal districts of the Republic of Crimea was chosen; for which a vector mask of agricultural lands was created for them. When identifying unused lands to verify the classification and minimize errors, it is necessary to have data on the phenological phases of vegetation and field data on the structure of crops; use identification methods in a complex (expert, automatic classification with various approaches: random forest, vegetation index, arable land, etc.).
\end{abstract}

\section{Introduction}

To solve the problem of food provision the world's population, the issue of efficient use of land resources is relevant.

The collapse of the Soviet Union and the subsequent transition from a state command and administrative economy to a market economy had a significant impact on agriculture. Incomplete or unsuccessful agrarian reforms, loss of guaranteed markets for agricultural products, sharp decline in production subsidies and the collapse of the livestock sector led to the abandonment of large tracts of arable land [1].

Arable lands alone was withdrawn from the turnover of 38.4 million ha, which is comparable to the sown area of Germany, Italy and France combined [2]. Since the 2000s in the countries of Eastern Europe, the opposite trend is observed - intensive introduction of previously abandoned arable lands into agricultural circulation with significant differences in the driving forces of this process [3]. These processes are also observed in many regions of the European part of Russia, where the main role in the return to agricultural circulation of arable lands abandoned in the 1990-2000s belongs to large agricultural holdings [4]. After 2000, the exclusion of agricultural land from turnover in Russia continued beyond the regions of the Black Earth Region, especially in the NonBlack Earth Region and in the arid steppe territories [1].

\footnotetext{
*Corresponding author: dunaeva_e@ @niishk.ru
} 
In Federal Law No. 101 "Law on the turnover of agricultural land", an unused (abandoned) land plot is defined as a land plot that has not been used for three or more consecutive years from the date of the ownership right. In foreign countries, such land plots mean those lands that were previously cultivated but have not been used for more than five years [5-7]

The rational use of agricultural land is a priority in the Republic of Crimea. The solution to the issue of non-use of agricultural land in agricultural production, mainly arable land, is quite acute. The category of arable land includes not only cultivated fields, but also fallows, i.e., lands that have not been used for several years [8].

Arable land is farmland used for the production of crop products, mainly cereals. Fallow is arable land left uncultivated for a long period. During the first 2-3 years of downtime, arable land overgrows with annual and perennial plants; in the next 5-7 years, rhizome plants dominate on it. Subsequently, vegetation characteristic of steppe conditions develops. Further, unused arable land is overgrown with bushes and trees. It is clear, returning this territory to crop rotation is an expensive task. Besides, abandoned lands is a source of weediness of arable land, the elimination of which requires a lot of time and effort. One of the ways to reduce the amount of unused land is to transfer it from arable land to fallow. The reason for such transfer may be a desire to veil the problem of abandoned lands since it is easier to rename one type of land to another, which does not imply tillage. Unused abandoned lands are also called "fallows". This term refers to agricultural land previously used as arable land, but not used for more than a year, starting in the fall, for sowing crops and for fallow.

Although abandoned agricultural lands monitoring is a priority for many national agricultural monitoring programs [9-10], there are no consistent maps of abandoned agricultural lands and reliable approaches for producing such maps from satellite data. Abandonment of agricultural lands is defined as agricultural lands that has not been used for at least two to five years [11-12]. It is necessary to distinguish perennial fallow (abandoned) from temporary fallow fields, which are part of the crop rotation cycle.

Many contemporary authors agree that in order to clarify and establish the location of land management objects, their boundaries, identify unused, irrationally used or used for other purposes and not according to the permitted use, it is necessary to conduct an inventory of land [13-14].

Most of the abandoned lands are not put on the cadastral register, the land surveying procedure has not been carried out for them, therefore, the Unified State Register of Real Estate contains only general, unspecified information about such sites. Thus, today the statistical information does not reflect the real state of affairs, moreover, the data of various government bodies and departments often contradict each other. The above factors affect the quality of plans for inspections of land within the framework of land control. A clear picture of land use is possible when implementing the following programs: conducting a general land inventory or developing and implementing local measures at the local authorities for updating data and reconciling documentary information with the situation on the soil [15].

The implementation of any measures to involve unused lands in agricultural circulation will be ineffective without land management.

As was mentioned above, abandoned arable lands means those lands that were previously cultivated (that is, they belong to the class of agricultural land), but have not been used for more than five years [5-7]. State law says, that a land plot is considered unused if it has not been used for three or more consecutive years from the day the ownership right arose. There is no information about a period during which the land could not be used for its intended purpose due to natural disasters or in the light of other factors 
precluding such use, as well as the development period (the development period is not more than two years).

There are various methods for identifying unused lands. Using GIS technologies with remote sensing data makes it possible to detect the spatial distribution of abandoned agricultural lands and determine their percentage, as well as to reveal the rate of change in dynamics.

Identification of unused lands by satellite observations is based on the analysis of the spectral response and the features of their texture characteristics. Because these lands have a set of specific properties, some problems in their identification can be identified by modern geographic information systems and technologies, as well as remote sensing data.

Numerous studies in the field of remote indication and monitoring of agricultural lands withdrawn from circulation are based on the use of time series of remote sensing data of low and medium resolution and are focused on analyzing the patterns of spatio-temporal differentiation of changes in the structure of agricultural land use determining the time of withdrawal from circulation and the nature of deposit lands overgrowing on macro-regional and regional levels [16-19].

In the work [20] the comparison of multi-time images over a three years' period helps to identify unused agricultural lands. Maps of unused lands, created on the basis of satellite imagery, can serve as an additional source of information for supervisory authorities making decisions on land acquisition. Based on the joint use of such maps and additional information (soil fertility, overgrowing of trees and shrubs, etc.), decisions can be made on the advisability of involving land in agricultural circulation.

In many studies, remote sensing information is used as additional to field and cartographic materials for detecting land types, visual identification of aerospace images [21], analysis of multi-temporal images [22], combination of different bands [23-25] and use of training samples for image classification, methods of automatic clustering by the magnitude of spectral brightness coefficient [26], etc.

At the same time, in many cases, Kovaleva and Lisetsky note [27], that even the use of ultra-high resolution data does not allow reliably determining the type of land. Different ages of unused lands, difficulty of creating a single spectral standard even for the territory of one administrative region, presence of plowing traces on young fallow lands, small size of individual fallow areas, identity of spectral response of fallow lands and vegetation of gullies and ravines significantly complicate the identification of unused lands. Unequal age of deposits can substantially affect the composition of phytocenoses. Composition of vegetation and its projective cover can also largely vary. For these reasons, it is very problematic to create a universal spectral standard for unused lands. This leads to almost exclusive possibility of identifying deposits visually by comparing various combinations of channels of multispectral satellite images.

Possibilities of using the series of spectral indicators for detecting and assessing the unused lands state is remaining poorly studied. This is mainly due to the lack of reliable field information about deposits, which would make it possible to form a representative sample and assess their spectral and brightness characteristics. To identify unused lands, information about plants phenological phases of used agricultural fields, the timing of sowing and harvesting is needed to compare the growth dynamic of natural vegetation.

Löw et. al [28] proposed an object-oriented approach to identify abandoned agricultural lands in Central Asia, based on joint use of support vector machine (SVM) and random forest (RF) when classifying the Landsat and RapidEye images. Classification accuracy was very high $-97 \%$.

Expert judgment method to obtain up-to-date information regarding classification and criteria for identifying abandoned agricultural lands is used in paper [29], where the review of publications included in Web of Science (WOS) and Current Contents (CC) databases 
for the period 1992 to 2019 dedicated to the identification of unused agricultural lands, based on remote sensing data, was carried out.

To identify abandoned lands, methods of random forest (RF) and support vectors [30], spatial and temporal segmentation of the time series of an improved set of satellite images [31] and the maximum likelihood method based on [32], as well as images of medium MODIS [3, 16, 30], high resolution Landsat and Sentinel [33] and Harmonized Landsat Sentinel-2 [31] are used.

Despite the problems in identifying abandoned lands in the world, maps of abandoned lands have been developed. Some of them are listed below:

- map of abandoned croplands with a resolution of $30 \mathrm{~m}$ for several survey sites in Russia, Poland and Lithuania covering the period 1990-2000 [34];

- map of agricultural land-cover change in the Republic of Kazakhstan for the period 1953-2010 based on Landsat [35];

- map of farmland abandonment and recultivation across Europe [3] using MODIS NDVI time series for the period 2001-2012;

- hybrid map of arable and abandoned lands across former Soviet Union countries [19];

- mapping of afforestation on abandoned lands in the European part of former Soviet Union made on base LANDSAT and GOOGLE EARTH ENGINE (https://maps.greenpeace.org/maps/aal/), which based on open spatial data and Greenpeace materials, in collaboration with the Global Land Analysis and Discovery Team (GLAD), University of Copenhagen and Kazan Federal University and include: field survey points - fields point from 2019 with photo and description; validation process areas; dom dataset for validation; afforestation_map_v2_1 - last version for European Part of former Soviet Union; hybrid map of arable land of former Soviet Union [19].

Spatial and temporal extent of these maps is different, as are the methods for identifying abandoned arable lands, making it impossible to directly compare these maps.

Current trend indicates that not all lands, suitable for agricultural production [36], is used and those, involved in the turnover, are not always properly used. Therefore, the identification and spatial localization of such lands is a key task to increase the efficiency of the land fund of the Republic of Crimea use and ensure the food provision of the region.

\section{Materials and methods}

Crimea is a zone of risky farming system by climate conditions. Agriculture is mainly crop production, focused on the cultivation of grain crops in rainfed agronomy. In the steppe and foothill zones of the region, southern chernozems of various types are the most common: medium and heavy loamy, slightly humus, as well as dark chestnut soils. Saline soils solonetz - are widespread along the coast of the Black and Azov Seas in the Sivash region, as well as in the southwestern part of the Kerch Peninsula.

Fig. 1 shows vegetation map of Crimea downloaded from the Vega-Science service in the form of georeferenced raster. In total, there are 1086347.9 hectares of agricultural land on the territory of the municipal districts, the largest area of which is occupied by arable land - 869702.9 hectares. 


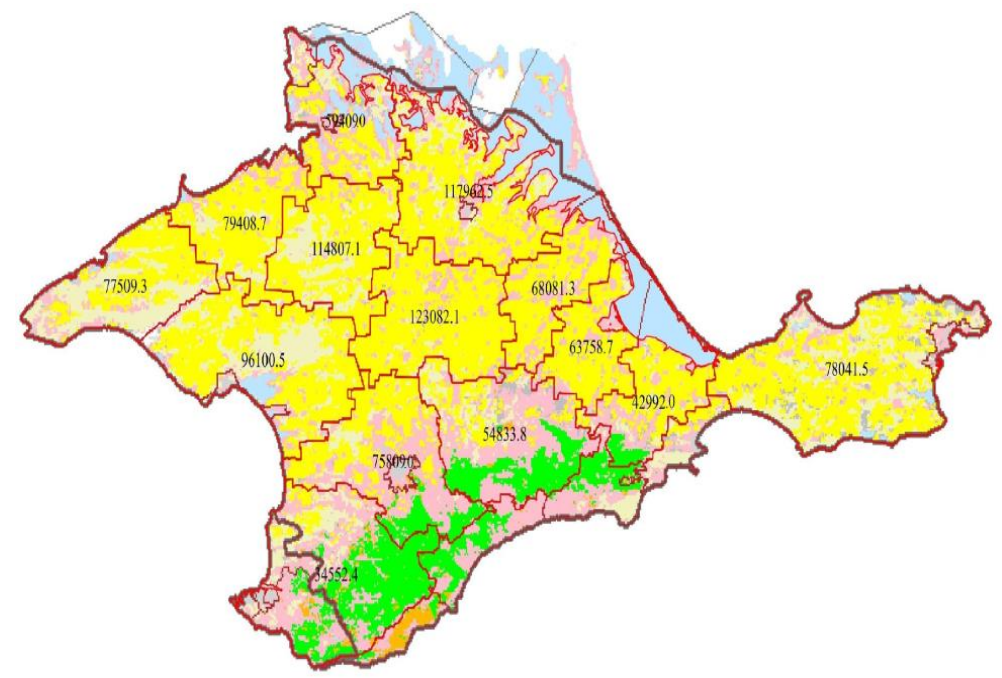

Legend

arable land

coniferous forest

desiduous forest

grassland

steppe

bare ground

water bodies

urbanized areas

54833.8 agricultural areas

Fig. 1. Vegetation map of Crimea in the form of georeferenced raster.

According to official data of the Ministry of Agriculture of the Republic of Crimea, in 2018, the total area of agricultural lands was 1.87 million hectares, 178 thousand hectares are not used in agricultural production, so $10 \%$ of agricultural lands is "idle". Most of these lands are in the Leninsky district (over 30\%), more than 13\% - in Dzhankoysky and nearly $7-8 \%$ - in the Bakhchisaraisky, Belogorsky and Chernomorsky regions. In other regions and urban districts of the Republic of Crimea, the area of unused agricultural lands does not exceed $5 \%$ of the total area of agricultural lands (according to information voiced in an interview by the Minister of Agriculture of the RC). In 2019, the total area of Crimean unused agricultural lands was 276 thousand ha, which is $15 \%$ of the Republic total area. Moreover, the largest areas of such lands were identified in the Dzhankoy and Simferopol regions. According to the report of the Ministry of Agriculture of Crimea on the work carried out to attract unused agricultural lands into circulation, it was transferred 65 thousand hectares for 2014-2019. It is planned to transfer 180 thousand hectares in 2020, unclaimed land area - 64 thousand hectares. 


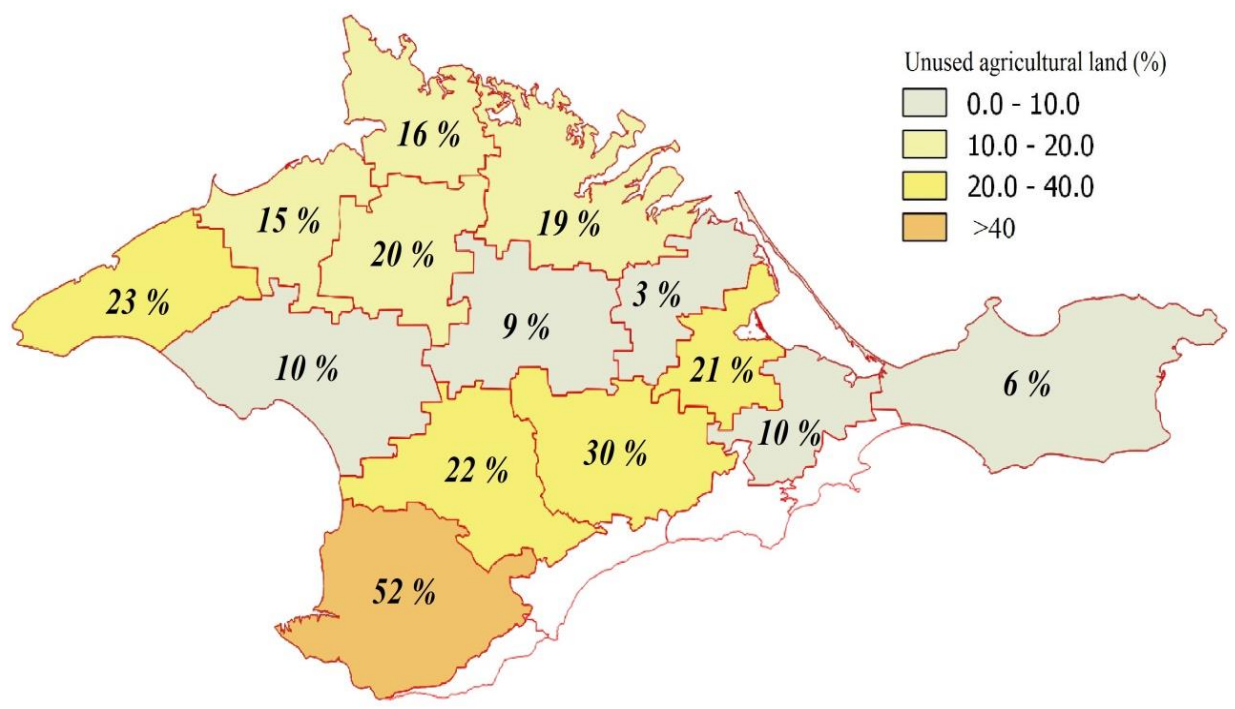

Fig. 2. Amount of unused agricultural lands in the Republic of Crimea.

Fig. 2 shows amount of unused agricultural lands in the context of municipal districts of the Republic of Crimea as a percentage according to statistical data of the All-Russian Agricultural Census of 2016 on the territory of the Republic of Crimea (data on the actually used area of agricultural land and the total area of agricultural lands).

According to statistics, unused agricultural lands include:

- organizations that ceased to exist due to bankruptcy, but for which the issue of termination of land rights has not been resolved;

- lands of agricultural organizations that are not legally liquidated, but in fact do not carry out financial and economic activities;

- unused land redistribution fund;

- unclaimed land shares.

- To identify unused or abandoned lands, it is important to know the factors that determine the reasons for its unusing:

- lack of economic opportunities to involve these lands in active agricultural turnover, to maintain and restore their fertility;

- economic inexpediency of use of agricultural land due to existing territorial disadvantages of land use;

- natural and anthropogenic processes of land degradation, development of negative processes leading to a decrease in land fertility and impossibility of using them for their intended purpose;

- presence of significant number of unclaimed land shares (issues of land unbundling and non-entry of heirs into the ownership of land plots - share of 4-8 hectares);

- migration of rural population, leading to an increase in abandoned rural settlements and overgrowing of land with trees and shrubs.

Shortage of family members to cultivate the land and the fragmentation of land are important factors in land abandonment. Spatial characteristics are less important, except certain soil types that are favourable to cultivation and designation in accordance with agricultural land protection policies. These conclusions were drawn from about 800 semistructured field interviews conducted to determine site and location characteristics, farming practices and household characteristics [34]. 


\section{Results and discussion}

To identify abandoned lands in Crimea, the MODIS time series analysis method of remote sensing data was used together with field data on the location of arable land using VegaScience service.

To detect such lands, the territory of Krasnogvardeisky and Belogorsky municipal districts of the Republic of Crimea was selected, for which a vector mask of agricultural lands was created. Methodology is based on the elimination of unused lands, i.e. first, those fields that are not uniquely unused: plowed fields, fields with actively growing vegetation, as well as those fields where there are traces of recent mowing of perennial grasses or grain harvesting will be excluded. This procedure is carried out using the Vega-Science satellite monitoring service, as well as the Quantum GIS 2.18.23 software. Taking into account the visual analysis of series of satellite images and time course of NDVI vegetation index; signs of non-use of agricultural land are established.

Based on export of data - 7-day NDVI values by MODIS (interpolation) in * .csv format from the VEGA-Science service, a graph of NDVI curves for winter and spring crops, fallows, as well as unused lands was obtained (Fig. 3). The graph shows the dynamics of vegetation growth and the nature of vegetation. According to data of production unit of the Research Institute of Agriculture of Crimea, operating in the village Klepinino of Krasnogvardeisky district of the Republic of Crimea, the phenological phase of winter cereals earing begins approximately at 18-19 week (May), for spring cereals - 2021 week (May), depending on sowing and weather conditions, which is reflected in the graph of winter crops curve in the form of maximum (peak) NDVI values (in the figure, they are indicated by dotted lines).

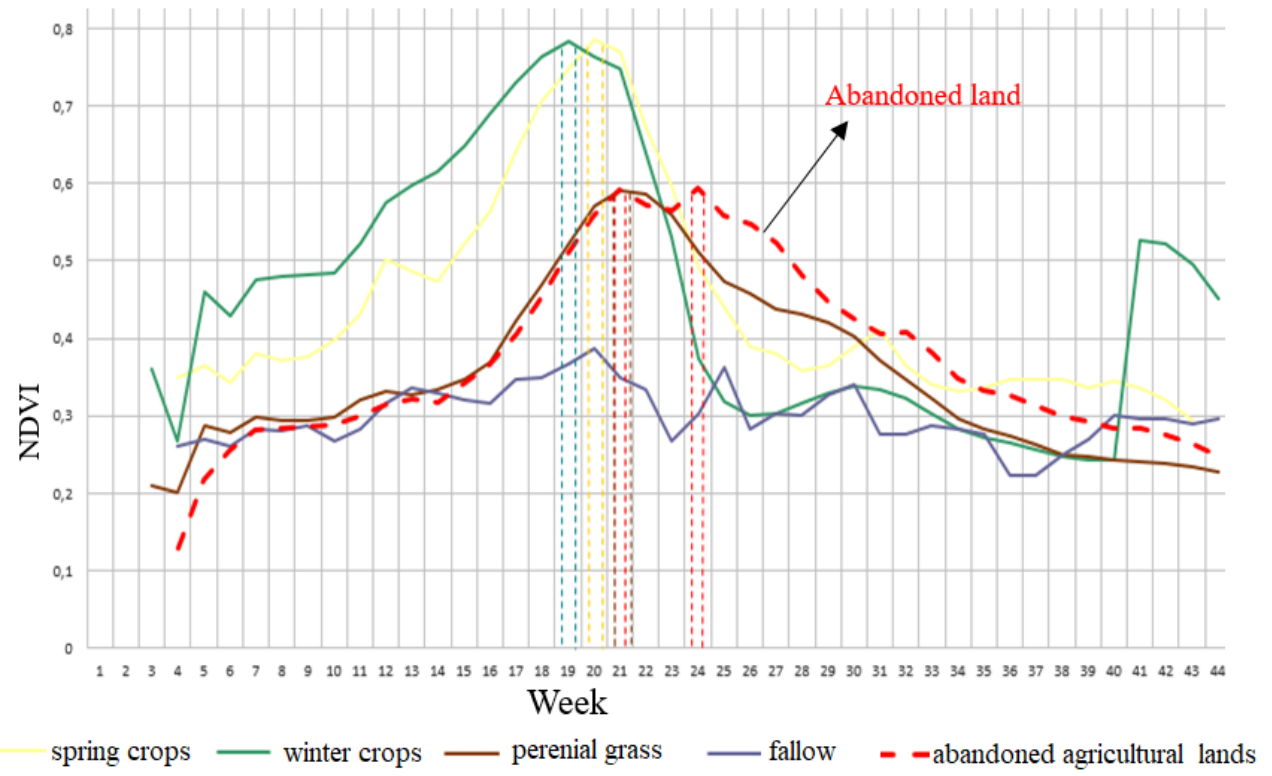

Fig. 3. The graph of course of NDVI curves in the fields of the Krasnogvardeisky district of the Republic of Crimea.

In this service on the tab "Analysis of the state. Analysis of the observation series of the object", it is possible to compare visually the graph of studied field with "standard", which makes it possible to more accurately make decisions about the type of crop in the field. Information on agricultural fields, entered in VEGA-Science, based on number of 
diagnostic features for 2018-2019, was described above. This information for each field, including the characteristic of vegetation (crop and its type), is displayed on "List of fields" tab.

By excluding winter crops, spring crops, perennial crops and fallow from agricultural land mask, we get a map of unused lands. At the next stage, it is planned to verify the obtained results by natural methods.

Thus, we can say that the most suitable period for detecting unused, abandoned lands is June-July.

Using Semiautomatic Classification together with data on structure of crops and timing of phenophases showed the possibility of accurate identification of agricultural crops (winter and spring), however, to identify abandoned lands, it is necessary to create a training sample for further research.

The assess of the Greenpeace service map for the territory of the Belogorsky region, which provides information on spatial localization of the processes of abandoned lands overgrowing with forests, based on Landsat satellite images and Google Earth Engine [19], was carried out. For this, the district territory was divided into a grid with squares (cells) $1 \times 1 \mathrm{~km}$ (total number of squares is 285). Sample consisted of squares containing the boundaries of agricultural fields and data filling by 30-100\% (188 squares), squares with less than $30 \%$ filling and empty squares were not involved.

To assess the quality of this map, 28 diagonal agricultural fields were selected. Fig. 4 shows the map created by Greenpeace, on which active croplands, as well as croplands, abandoned from 3 to 5 years, fallow land (afforested) abandoned at least 20 years are mapped.

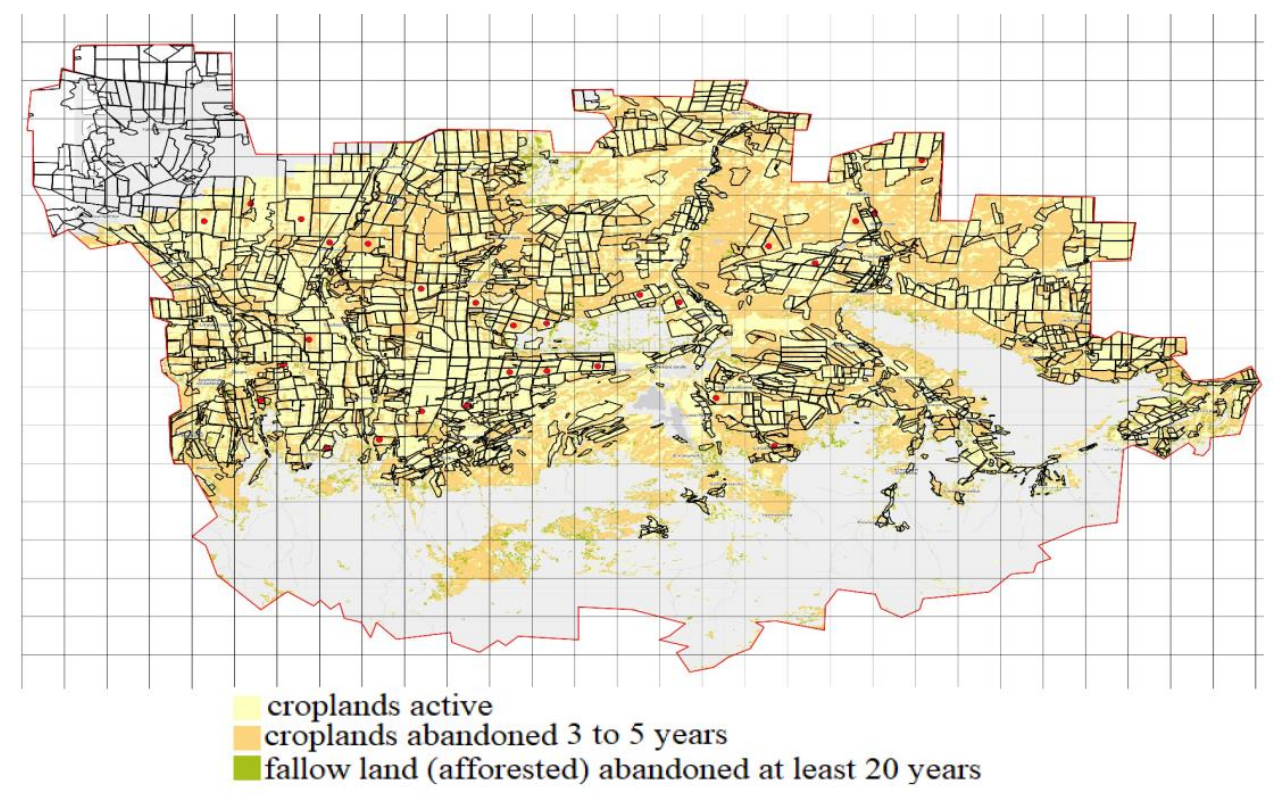

Fig. 4. The map of active and abandoned croplands, created by Greenpeace.

Based on 7-day NDVI values according to MODIS (interpolation), presented on the VEGA-Science service, the comparison of NDVI course in agricultural fields with the average long-term NDVI course in arable land ("norm") was made (Fig. 5). 
a)

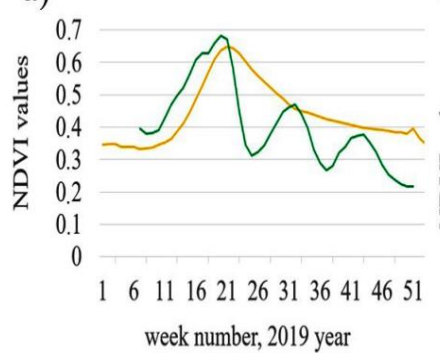

b)

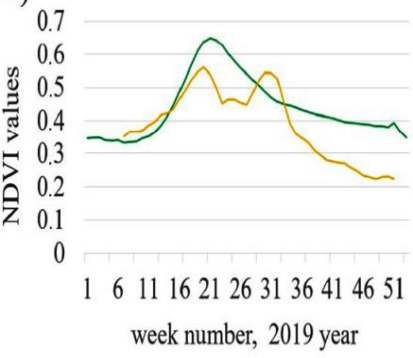

c)

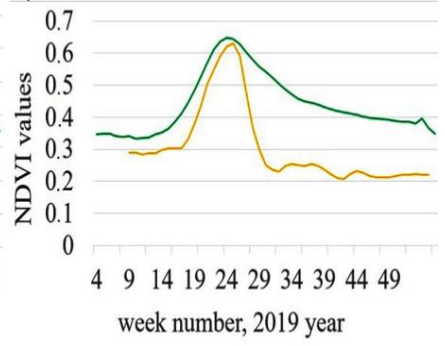

\section{- long-term average NDVI dynamics -NDVI}

Fig. 5. Comparison of NDVI course in agricultural fields with the average long-term NDVI course in arable land: a) field was identified as unused (according to field data - the field on which winter barley was cultivated); b) field was identified as being used (NDVI is not typical for used cropland); c) field was identified as in use (NDVI progress graph is typical for used cropland).

According to the Greenpeace map, 20 fields were used; and 8 were not used. However, when evaluating the values of NDVI course, it was found that out of 28 investigated fields, 23 fields are arable; and 5 are not arable.

Using the raster image vectorization procedure, it was found that the amount of unused agricultural land in the Belogorsky region according to the Greenpeace map is 39290.5 hectares, which is 22964.7 hectares $(58.5 \%)$ more than the official statistics. This may arise due to the inclusion of pastures, fallow lands, deposit lands, as well as lands of settlements in unused lands. Absence of masks for settlements and agricultural fields reduces the accuracy of land identification.

Table 1. Matrix of errors in determining the using of agricultural land in the Belogorsky region.

\begin{tabular}{|c|c|c|c|}
\hline Parameter/ area, ha & $\begin{array}{c}\text { According to } \\
\text { Greenpeace service }\end{array}$ & $\begin{array}{c}\text { According to } \\
\text { statistical data }\end{array}$ & $\begin{array}{c}\text { Deviation } \\
\text { (absolute, ha / } \\
\text { relative, \%) }\end{array}$ \\
\hline Used lands & 48574.6 & 38508.0 & $10066.6 / 20.7$ \\
\hline Unused lands & 39290.5 & 16325.8 & $22964.7 / 58.5$ \\
\hline
\end{tabular}

Fig. 6 shows the map of active and abandoned croplands in the Krymskorozovsky rural settlement of the Belogorsky district created by Greenpeace. 


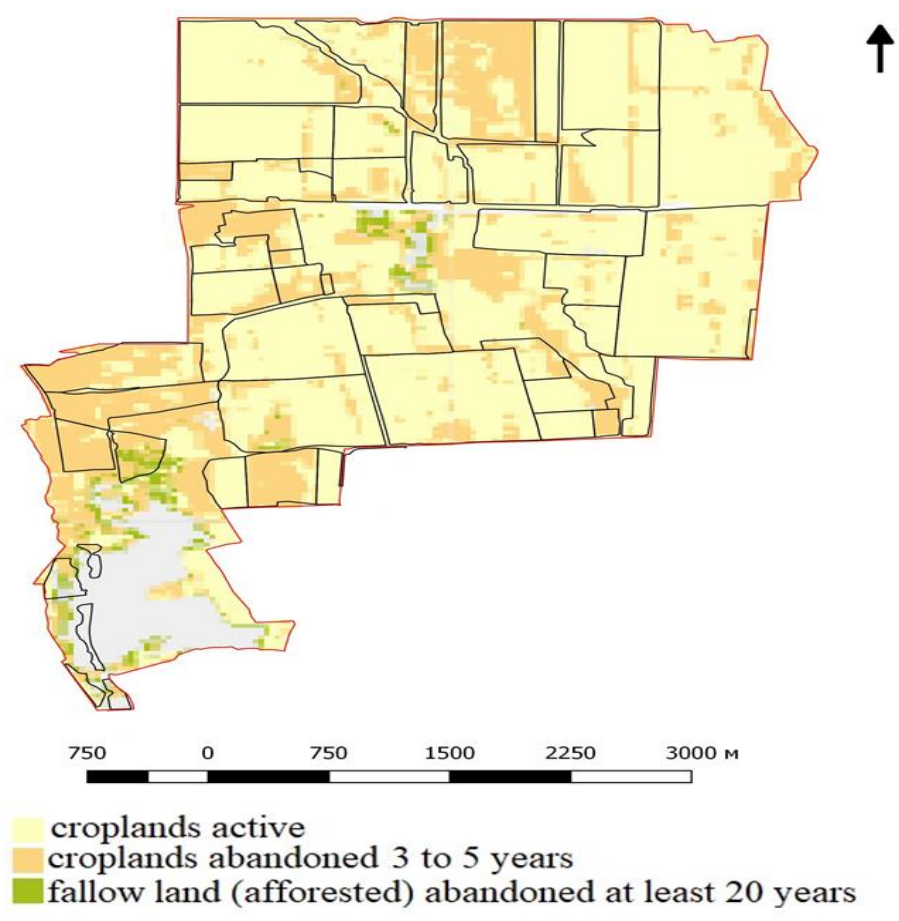

Fig. 6. The map of active and abandoned croplands in the Krymskorozovsky rural settlement of the Belogorsky district, created by Greenpeace.

According to the Greenpeace map, 282 hectares of agricultural lands in the Krymskorozovsky rural settlement of the Belogorsky district is not used. This is erroneous. Since, according to the data on the structure of sown area of this settlement, all agricultural lands are used in agricultural production. Note that the field, overgrown with shrubby vegetation, was identified correctly.

\section{Conclusions}

In Crimea, the main reasons of agricultural land abandonment are overuse (soil depletion), humus decreasing and return of soil salinity.

Today, some method is mainly used to identify unused lands, which gives some errors. Most researchers use vegetation indices and their comparison to assess the state of agricultural lands at different seasons of the year from several multi-seasonal images.

Also, the main part of the research is aimed at assessing the dynamics of overgrowth of arable lands with woody vegetation. There are developments in the identification of abandoned lands due to their salinity and / or unrecultivated quarries.

Thus, when identifying unused lands to verify the classification and minimize errors, it is necessary to have data on the phenological phases of vegetation and field data on the structure of crops; use identification methods in a complex (expert, automatic classification with various approaches: random forest, vegetation index, arable land, etc.).

The reported study was funded by theme \#0834-2015-0015 (AAAA-A16-116022610123-9). 


\section{References}

1. Meyfroidt P, Schierhorn F, Prishchepov AV, Müller D and Kuemmerle T 2016 Drivers, constraints and trade-offs associated with recultivating abandoned cropland in Russia, Ukraine and Kazakhstan J. Glob. Envir. Change 37 1-15

2. Shutkov A A and Shutkov S A 2017 Innovation policy as the basis for economic modernization Proc. Conf. Russia: trends and development prospects 01-30 December (Moscow) 641-46

3. Estel S, Kuemmerle T, Alcántara C, Levers C, Prishchepov A and Hostert P 2015 Mapping farmland abandonment and recultivation across Europe using MODIS NDVI time series J. Remote Sens. Environ. 163 312-25

4. De Beurs K M and Ioffe G 2014 Use of Landsat and MODIS data to remotely estimate Russian sown area J. of Land Use Science 9(4) 377-401

5. Schierhorn F, Müller D, Beringer T, Prishchepov A V, Kuemmerle T and Balmann A 2013 Post-Soviet cropland abandonment and carbon sequestration in European Russia, Ukraine, and Belarus J.Glob. Biogeochem. Cycles 27 1175-85

6. Ioffe G, Nefedova T and Zaslavsky I 2004 From spatial continuity to fragmentation: the case of Russian farming J. Ann. Assoc. Am. Geogr. $94913-43$

7. Saraykin V, Yanbykh R and Uzun V 2017 The Eurasian Wheat Belt and Food Security ed S G y Paloma S Mary at al. (Springer: Cham.) 155-75

8. Labutina I A and Baldina E A 2013 Workshop on the Course "Deciphering of Aerospace Images" (Moscow: Faculty of Geography State University) 168

9. Keenleyside C and Tucker G M 2010 Farmland Abandonment in the EU: an Assessment of Trends and Prospects (London: Institute for European Environmental Policy) Report prepared for WWF

10. Renwick A, Jansson T, Verburg P H, Revoredo-Giha C, Britz W, Gocht A and McCracken D 2013 Policy reform and agricultural land abandonment in the EU $J$. Land Use Policy 30(1) 446-57

11. FAO 2016 FAOSTAT Methods \& standards [WWW Document] URL http://www.fao.org/ag/agn/nutrition/Indicatorsfiles/Agriculture.pdf (accessed 26.04.2020)

12. Pointereau P, Coulon F, Girard P, Lambotte M, Stuczynski T, Sánchez Ortega V and Del Rio A 2008 Analysis of Farmland Abandonment and the Extent and Location of Agricultural Areas that are Actually Abandoned or are in Risk to be Abandoned EN (Luxembourg: Publications Office of the European Union JRC 46185) EUR 23411

13. Vershinin V and Petrov V 2015 Improving the mechanisms for involving unused agricultural land in agricultural circulation International Agric. Journ. 5 9-11

14. Lipsky S A 2017 How to ensure the rational use of shared agricultural land? J. Land manag., cadastre and land monit. $921-5$

15. Chernova U Y 2020 Main problems identify any unused agricultural land el. J. Diary of science 1(37) 18

16. Alcantara C, Kuemmerle T, Baumann M, Bragina E W, Griffiths P, Hostert P, Knorn J, Müller D, Prishchepov A V,Schierhorn F, Sieber A and Radeloff V C 2013 Mapping the extent of abandoned farmland in Central and Eastern Europe Using MODIS time series satellite data J. Environ. Res. Letters 8(3) 035035

17. Estel S, Kuemmerle T, Alcántara C, Levers C, Prishchepov A and Hostert P 2015 Mapping farmland abandonment and recultivation across Europe using MODIS NDVI 
time series J. Rem. Sensing of Envir. 163 312-25

18. Koroleva N V, Tikhonova E V, Ershov D V, Saltykov A N, Gavrilyuk N A and Pugachevsky A V 2018 Estimation of the scale of non-forest lands overgrowing in the national park "Smolenskoe Poozerie" for 25 years using Landsat satellite data $J$. Lesovedenie 2 83-96

19. Lesiv M. et al. 2018 Spatial distribution of arable and abandoned land across former Soviet Union countries J. Sci. Data 5180056

20. Kozubenko I S, Beglyarov R R, Vandysheva N M, Babak V A, Denisov P V and Troshko K A 2018 Use of remote sensing data in the integrated federal information system on agricultural lands (IFIS AL) 2nd All-Russ. Sci. Conf. "Application of earth remote sensing means in agriculture” (St. Petersburg) 19-25

21. Rukhovich D I and Shapovalov D A On the features of monitoring of soil and land cover as an information basis for effective land use J. Land manag., cadastre and monit. of lands 12 31-49

22. Klyushnikova N M 2013 Decoding of agricultural lands of the Volgograd Zavolzhye $J$. The facets of knowledge 3(23) 40-4

23. Kanatyeva N P 2013 Study of the transformation of arable land in the Northern Volga region according to remote sensing data J. Strategy for sust. Devel. of Russ. regions 17 132-37

24. Marinina O A, Terekhin EA, Kirilenko Z A, Kurlovich D M and Kovalchik N V 2013 Characteristics remote detection fallow land trust and problems of agricultural land use J. Mod. probl. of sci. and educ. Surgery 5535

25. Savin I Yu, Otarov A, Zhogalev A V, Ibrayeva M A and Duysekov S 2014 Long-term changes in the area of saline soils recognized by LANDSAT images in Shauldersk irrigated massive J. Dokuchaev Soil Bull. 74 49-65

26. Berezin L V 2015 The reflection of the solar radiation range in ecosystems on the materials of remote sensing of the earth J. Omsk SAU Bull. 4(20) 24-32

27. Kovaleva T N and Lisetsky F N 2012 Land management of agrolandscapes of Volga upland using modern software tools and data of space monitoring J. Sci. Bull. of BelSU 9(128) 166-72

28. Löw F, Fliemann E, Abdullaev I, Christopher C and Lamers J P A 2015 Mapping abandoned agricultural land in Kyzyl-Orda, Kazakhstan using satellite remote sensing J. Appl. Geogr. 62 377-90

29. Goga $\mathrm{T}$ et al. 2019 A review of the application of remote sensing data for abandoned agricultural land identification with focus on Central and Eastern Europe J. Remote Sens. 11(23) 2759

30. Löw F, Prishchepov A V, Waldner F, Dubovyk O, Akramkhanov A, Biradar C and Lamers P A 2018 Mapping cropland abandonment in the Aral Sea basin with MODIS time series J. Remote Sens. 10(2) 159

31. He Yin, Prishchepov A V, Kuemmerled T, Bleyhld B, Buchnera J and Radeloff V C 2018 Mapping agricultural land abandonment from spatial and temporal segmentation of Landsat time series J. Rem. Sens. of Envir. 210 12-24

32. Szatmári D, Kopecká M, Feranec J and Goga T 2018 Abandoned agricultural land mapping using sentinel-2a data 7th Int. Conf. on Cartography and GIS Proceedings June vol 1 and vol 2 (Sozopol Bulgaria) 18-23

33. Zhou T, Koomen E and Ke X 2020 Determinants of farmland abandonment on the urban-rural Fringe J. Envir. Managem. 65 369-84 
34. Prishchepov A V, Radeloff V C, Baumann M, Kuemmerle T and Müller D 2012 Effects of institutional changes on land use: agricultural land abandonment during the transition from state-command to market-driven economies in post-Soviet Eastern Europe J. Environ. Res. Lett. 7(2) 024021

35. Kraemer R, et al 2015 Long-term agricultural land-cover change and potential for cropland expansion in the former Virgin Lands area of Kazakhstan J. Environ. Res. Lett. 10(5) 054012

36. Kozlov G, et al 2020 Bioindication for the Search of Microorganisms-Destructors. Advances in Intelligent Systems and Computing 676-684 doi:10.1007/978-3-03057453-6_64 